\title{
Pengembangan Lembar Kerja Peserta Didik (LKPD) Berbasis Problem Based Learning (PBL) untuk Kelas VII SMP/MTs Mata Pelajaran Matematika
}

\author{
Astuti \\ Program Studi Pendidikan Matematika, Fakultas Ilmu Pendidikan, Universitas Pahlawan Tuanku Tambusai, \\ J1. Tuanku Tambusai No 23, Bangkinang, Indonesia \\ astutimasnur@email.com
}

\begin{abstract}
Abstrack
Learning tools are tools used in the learning process consisting of syllabus, learning implementation plan (RPP), teaching materials, and test learning results. One of the printed teaching materials used in the learning process in schools is the Student Worksheet (LKPD). The purpose of this research is to produce PBL-based LKPD for mathematics materials in semester I grade VIII SMP that are valid and practical. The type of research used is design research to develop and produce a product. The development model used was adapted from a model developed by Plomp and expressed as a Plomp research model. the validity of didactic aspects, content and language in problem-based learning LKPD has met the valid criteria with the a verage overall validity is 3.43 with a very valid category. Validation results from the validators show that $1 \mathrm{kpd}$ has been produced based on valid problem learning both in terms of content, construct, and language, with characteristics such as lkpd produced has been adapted to the characteristics of Problem Based Learning. Based on the questionnaire given to students that the practicality value is $90.2 \%$, then the questionnaire given to the teacher that the practicality value is $92 \%$, ba sed on the practicality table that the practical value of practicality is very practical. The results also showed LKPD meets practical criteria with characteristics, namely the ease of use of problem-based learning LKPD.
\end{abstract}

Keywords: Student Worksheet (LKPD), Problem Based Learning (PBL)

\begin{abstract}
Abstrak
Perangkat pembelajaran merupakan perangkat-perangkat yang digunakan dalam proses pembelajaran yang terdiri dari silabus, rencana pelaksanaan pembelajaran (RPP), bahan ajar, dan tes hasil belajar. Satu daribahan ajarcetak yang digunakan da lam proses pembelajaran di sekolah adalah Lembar Kerja Peserta Didik (LKPD). Tujuan dari penelitian ini adalah Menghasilkan LKPD berbasis $P B L$ untuk materi matematika semester I kelas VIII SMP yang valid dan praktis. Jenis penelitian yang digunakan adalah penelitian disain (Design Research) untuk mengembangkan dan menghasilkan sebuah produk. Model pengembangan yang digunakan dia daptasi dari model yang dikembangkan oleh Plomp dan dinyatakan sebagai model penelitian Plomp. validitas a spek didaktik, isi dan bahasa pada LKPD berbasis Problem based learning sudah memenuhi kriteria valid dengan rata -rata validitas secara keseluruhan adalah 3,43 dengan kategori sangat valid. Hasil validasi dari para validator menunjukkan bahwa telah dihasilkan LKPD berbasis Problem Based Learning yang valid baik dari segi isi, konstruk, dan bahasa, dengan karakteristik seperti LKPD yang dihasilkan telah disesuaikan dengan ciri-ciri dari Problem Based Learning. Berdasarkan angket yang diberikan kepada siswa bahwa Nilai praktikalitas 90,2 \%, kemudian angket yang diberikan kepada guru bahwa Nilai praktikalitas $92 \%$, berdasarkan tabel praktikalitas bahwa nilai praktikalitas bernilai sangat praktis. Hasil penelitian juga menunjukan LKPD memenuhikriteria praktis dengan karakteristik yaitu adanya kemudahan da lam pengguna an LKPD berbasis Problem Based Learning .
\end{abstract}

Kata kunci: Lembar Kerja Peserta Didik (LKPD), Problem Based Learning (PBL)

Copyright (c) 2021 Astuti

Corresponding author: Astuti

Email Address: astutimasnur@gmail.com (Jl. Tuanku Tambusai No 23, Bangkinang)

Received 03 April 2021, Accepted 16 April 2021, Published 16 April 2021

\section{PENDAHULUAN}

Perangkat pembelajaran adalah komponen yang harus disiapkan oleh guru sebelum melaksanakan pembelajaran. Dalam KBBI (2007), perangkat adalah alat atau perlengkapan, sedangkan pembelajaran adalah proses atau cara menjadikan orang belajar. Menurut Zuhdan, et.al (2011)perangkat pembelajaran adalah alat atau perlengkapan untuk melaksan akan proses yang memungkinkan pendidik 
dan peserta didik melakukan kegiatan pembelajaran. Perangkat pembelajaran menjadi pegangan bagi guru dalam melaksanakan pembelajaran baik di kelas, laboratorium atau di luar kelas.

Dalam Permendikbud No. 65 Tahun 2013 tentang Standar Proses Pendidikan Dasar dan Menengah disebutkan bahwa penyusunan perangkat pembelajaran merupakan bagian dari perencanaan pembelajaran. Perencanaan pembelajaran dirancang dalam bentuk silabus dan RPP yang mengacu pada standar isi. Selain itu, dalam perencanaan pembelajaran juga dilakukan penyiapan media dan sumber belajar, perangkat penilaian, dan skenario pembelajaran.

Matematika merupakan salah satu mata pelajaran yang sangat penting dalam dunia pendidikan, karena pelajaran matematika dapat membuat peserta didik berfikir logis, rasional, kritis dan luas, pernyataan ini sejalan dengan tujuan pendidikan nasional, yaitu: Mempersiapkan anak didik agar mampu menghadapi perubahan dalam kehidupan dan dalam dunia yang senantiasa berubah ini, melalui latihan bertindak atas dasar pemikiran logis, rasional, kritis, dan cermat juga untuk mempersiapkan anak didik agar mampu menggunakan matematika dalam kehidupan sehari-hari dan dalam mempelajari berbagai ilmu pengetahuan.

Matematika disebut ratu karena, dalam perkembangannya matematika tidak pernah bergantung kepada ilmu yang lain. Namun matematika selalu memberikan pelayanan kepada berbagai cabang ilmu pengetahauan untuk mengembangkan diri, baik dalam bentuk teori, terlebih dalam aplikasinya. Banyak aplikasi dalam berbagai disiplin ilmu, menggunakan matematika, terutama dalam aspek penalarannya. Oleh sebab itu, kedewasaan suatu ilmu ditentukan oleh ada tidaknya ilmu tersebut menggunakan matematika dalam pola pikir maupun pengembangan aplikasinya (Kamarullah, 2017).

Menyadari pentingnya peranan matematika maka mengoptimalkan hasil belajar matematika peserta didik disetiap jenjang pendidikan perlu mendapat perhatian yang sungguh-sungguh agar tujuan dari pendidikan nasional tersebut dapat tercapai. Prosespembelajaran matematika dapat berjalan dengan baik dan dapat mencapai tujuan yang diharapkan untuk itu perlu adanya suatu tindakan atau perubahan yang signifikan dari pihak guru dan peserta didik.

Matematika sekolah berfungsi mengembangkan kemampuan menghitung, mengukur, menurunkan dan menggunakan rumus matematika yang diperlukan dalam kehidupan sehari-hari diantaranya melalui materi pengukuran dan geometri, aljabar dan trigonometri. Matematika juga berfungsi mengembangkan kemampuan mengkomunikasikan gagasan dengan bahasa melalui model matematika yang dapat berupa kalimat dan persamaan matematika, diagram, grafik, atau table (Rahmah, 2018).

Salah satu penentu keberhasilan proses pembelajaran dankeberhasilandalam pencapaian tujuan pembelajaran matematika adalah perangkat pembelajaran. Perangkat pembelajaran merupakan perangkat-perangkat yang digunakan dalam proses pembelajaran yang terdiri dari silabus, rencana pelaksanaan pembelajaran (RPP), bahan ajar, dan tes hasil belajar. Satu dari bahan ajar cetak yang digunakan dalam proses pembelajaran di sekolah adalah Lembar Kerja Pe serta Didik (LKPD). 
Banyak guru yang merasa sulit mencari buku literatur matematika yang baik sebagai sumber pembelajaran. Hal ini juga disebabkan karena kurangnya kemampuan guru dalam memahami buku teks berbahasa inggris. Sedangkan buku terjemahan yang ada satu-dua, harganya tidak terjangkau oleh guru maupun siswa. kebanyakan buku yang tersedia adalah buku paket; itu pun sebagian besar disusun secara serampangan dan tidak jarang salah konsep (Kamarullah, 2017).

LKPD adalah salah satu bahan ajar cetak yang dapat mempermudah peserta didik untuk berinteraksi dengan materi yang diberikan. LKPD dapat membantu peserta didik untuk aktif dalam proses pembelajaran karena berisikan aktivitas yang melibatkan peserta didik. Melalui LKPD peserta didik juga dapat dibimbing untuk menemukan kembali suatu konsep. LKPD dapat mempermudah guru dalam melaksanakan proses pembelajaran. Selain itu LKPD juga kaya akan tugas untuk berlatih.

LKPD yang banyak beredar di sekolah-sekolah saat ini masih bersifat umum dan sebagian besar hanya berisi ringkasan materi. Materi yang disajikan biasanya bersifat instan tanpa disertai penjelasan detail dan tidak ada petunjuk penggunaan LKPD bagi guru dan siswa. Hal ini akan menyebabkan peserta didik kurang tertarik pada LKPD yang ada dan kurang mengasah kemampuan berpikir kritis peserta didik. Serta pengemasan materi yang cenderung kurang bermakna bagi siswa menyebabkan peserta didik hanya menghafal materi tanpa memahami konsep yang ada sehingga mudah dilupakan dan ketika diberikan soal yang sedikit bervariasi, peserta didik akan mengalami kebingungan (Astuti et al., 2018).

Berdasarkan hasil observasi LKPD yang digunakan selama ini belum dapat memberikan kesempatan kepada peserta didik untuk dapat mencapai tujuan pembelajaran yang diinginkan, sehingga belum dapat secara optimal meningkatkan hasil belajar peserta didik. Berdasarkan analisis yang dilakukan pada beberapaLKPD, didapati bahwa LKPD tersebut hanya menyajikan materi pembalajaran, yang dilanjutkan dengen memberikan latihan-latihan soal. Selain itu, diperoleh bahwa hampir sebagian besar soal-soal LKPD hanya membelajarkan peserta didik untuk mengingat (C1), memahami (C2), dan menerapkan (C3). Agar lebih optimalnya ketercapaian tujuan pembelajaran matematika yang pada akhirnya dapat meningkatkan hasil belajar matematika maka perlu dilakukan perbaikan pada LKPD tersebut yaitu dengan memberikan kegiatan yang dapat membimbing peserta didik untuk dapat mengembangkan kemampuan matematisnya.

LKPD akan semakin optimal jika berlandaskan pada salah satu model atau strategi pembelajaran yang memiliki tujuan untuk meningkatkan kemampuan matematis peserta didik terutama kemampuan pemecahan masalah. Hasil studi Sumarmo (Annisa, 2014: 2) menunjukkan bahwa keterampilan menyelesaikan soal pemecahan masalah siswa sekolah menengah atas ataupun siswa sekolah menengah pertama masih rendah. Supriatna (2011: 5) juga memberikan gambaran bahwa soal-soal pemecahan masalah belum dikuasai oleh peserta didik. (Wirdaningsih et al., 2017)

Salah satu model/ strategi pembelajaran yang dapat digunakan untuk menc apai tujuan tersebut adalah melalui Problem Based Learning (PBL). Berdasarkan penelitian yang dilakukan oleh Vebdola, Niniawati, dan Fauziah (2013:9) tentang penerapan strategi $P B L$ dalam pembelajaran matematika, diperoleh kesimpulan bahwa hasil pembelajaran $P B L$ lebih baik dari hasil belajar matematika peserta 
didik yang menggunakan pembelajaran konvensional. Beberapa penelitian tentang PBL telah digunakan untuk meningkatkan kemampuan pemecahan masalah matematis (Reski, Hutapea, \& Saragih, 2019), kemapuan literasi (Hidayat, Roza, \& Murni, 2019), selainitu dapat juga digunakan untuk membantu siswa mengembangkan keterampilan berpikir, keterampilan menyelesaikan masalah, dan keterampilan intelektualnya (Sumartini, 2015, hlm. 2). Oleh karena itu, Model pembelajaran ini bisa digunakan untuk meningkatkan kemampuan representasi siswa melalui penyelesaian masalah, sehingga siswa dilibatkan secara aktif dalam proses maupun perolehan hasil penyelesaian masalah. Hal ini dapat diketahui dari salah satu fase yang terdapat pada fase membimbing penyelidikan individu dan kelompok. Siswa dituntut untuk dapat memahami, mengidentifikasi dan mengkontruk pengetahuaanya dalam menyelesaikan masalah pada LKPD (Susanti et al., 2019).

Kemampuan pemecahan masalah sangat penting dimiliki oleh setiap siswa karena (a) pemecahan masalah merupakan tujuan umum pengajaran matematika, (b) pemecahan masalah yang meliputi metoda, prosedur dan strategi merupakan proses inti dan utama dalam kurikulum matematika, dan (c) pemecahan masalah merupakan kemampuan dasar dalam belajar matematika (Branca, 1980) (Sumartini, 2018). Ruseffendi (1991) mengatakan bahwa kemampuan pemecahan masalah sangat penting dalam matematika, bukan saja bagi mereka yang dikemudian hari akan mendalami atau mempelajari matematika, melainkanjuga bagi merekayang akan menerapkannya dalam bidang studi lain dan dalam kehidupan sehari-hari.

Pada penelitian ini hasil belajar fokus pada kemampuan pemecahan masalah matematis peserta didik Menurut Polya (dalam Ruseffendi, 1991) mengemukakan bahwa untuk memecahkan suatu masalah ada empat langkah yang dapat dilakukan, yakni: 1. Memahami masalah. Kegiatan dapat yang dilakukan pada langkah ini adalah: apa (data) yang diketahui, apa yang tidak diketahui (ditanyakan), apakah informasi cukup, kondisi (syarat) apa yang harus dipenuhi, menyatakan kembali masalah asli dalam bentuk yang lebih operasional (dapat dipecahkan). 2. Merencanakan pemecahannya. Kegiatan yang dapat dilakukan pada langkah ini adalah: mencoba mencari atau mengingat ma salah yang pernah diselesaikan yang memiliki kemiripan dengan masalah yang akan dipecahkan, mencari pola atau aturan, menyusun prosedur penyelesaian (membuat konjektur). 3. Menyelesaikan masalah sesuai rencana. Kegiatan yang dapat dilakukan pada langkah ini adalah: menjalankan prosedur yang telah dibuat pada langkah sebelumnya untuk mendapatkan penyelesaian. 4. Memeriksa kembali prosedur dan hasil penyelesaian. Kegiatan yang dapat dilakukan pada langkah ini adalah: menganalisis dan mengevaluasi apakah prosedur yang diterapkan dan hasil yang diperoleh benar, atau apakah prosedur dapat dibuat generalisasinya (Sumartini, 2018).

Problem Based Learning merupakan suatu model pembelajaran yang menggunakan masalah dunia nyata sebagai konteks bagi siswa untuk belajar tentang cara berpikir kritis dan keterampilan pemecahan masalah, serta untuk memperoleh pengetahuan yang esensial dari materi pelajaran. Problem Based Learning membantu siswa untuk menerapkan pemahaman suatu konsep, dengan terlebih dahulu 
Pengembangan Lembar Kerja Peserta Didik (LKPD) Berbasis Problem Based Learning (PBL) untuk Kelas VII SMP/MTs Mata Pelajaran Matematika, Astuti

diberikan masalah di awal pembelajaran untuk didiskusikan dan diselesaikan secara bersama-sama. Adapun masalah yang diberikan disesuaikan dengan jangkauan pemikiran dan kebutuhan siswa (Rifa'i, 2019). Keterangan di atas juga sejalan dengan Kunandar yang mengatakan bahawa Problem Based Learning $(P B L)$ adalah suatu model pembelajaran ataupun pendekatan pembelajaran yang menggunakan masalah dunia nyata sebagai suatu konteks atau masalah bagi peserta didik untuk belajar tentang cara berpikir kritis dan keterampilan pemecahan masalah, serta dapat memperoleh pengetahuan dan konsep yang esensial dari materi pelajaran (Kunandar, 2011). Langkah-langkah Problem Based Learning menurut Kunandar (2008) sebagai berikut:
a. Orientasi siswa pada masalah
b. Mengorganisasikan siswa untuk belajar
c. Membimbing penyelidikan individual maupun kelompok
d. Mengembangkan dan menyajikan hasil karya
e. Menganalisa dan mengevaluasi proses pem ecahan masalah (Suhendar \& Ekayanti, 2018)

Tahap pelaksanaan pembelajaran dengan menggunakan model pembelajaran PBL dapat dilihat pada tabel berikut menurut (Nafiah \& Suyanto, 2014):

Tabel 1. Fase dalam PBL

\begin{tabular}{|l|l|}
\hline \multicolumn{1}{|c|}{ Fase dalam PBL } & \multicolumn{1}{c|}{ Perilaku Guru } \\
\hline $\begin{array}{l}\text { Fase 1 Memberikan orientasi } \\
\text { tentang permasalahannya kepada } \\
\text { siswa }\end{array}$ & $\begin{array}{l}\text { Guru membahas tujuan pembelajaran, mendeskripsikan } \\
\text { berbagai kebutuhan logistik penting, dan memotivasi siswa } \\
\text { untuk terlibat dalam kegiatan mengatasi masalah }\end{array}$ \\
\hline $\begin{array}{l}\text { Fase 2 Mengorganisasikan siswa } \\
\text { untuk meneliti }\end{array}$ & $\begin{array}{l}\text { Guru membantu siswa untuk mendefinisikan dan } \\
\text { mengorganisasi }\end{array}$ \\
\hline $\begin{array}{l}\text { Fase 3 Membantu investigasi } \\
\text { mandiri dan berkelompok; }\end{array}$ & $\begin{array}{l}\text { Guru mendorong siswa untukmendapatkan informasi yang } \\
\text { tepat, melaksanakan eksperimen, dan mencari penjelasan } \\
\text { dan solusi }\end{array}$ \\
\hline $\begin{array}{l}\text { Fase 4 Mengembangkan dan } \\
\text { mempresenta }\end{array}$ & $\begin{array}{l}\text { Guru membantu siswa dalam merencanakan dan } \\
\text { menyiapkan artefak-artefak yang tepat seperti laporan, } \\
\text { rekaman video, dan model-model yang membantu mereka } \\
\text { untuk menyampaikannya kepada orang lain. }\end{array}$ \\
\hline $\begin{array}{l}\text { Fase 5 Menganalisis dan } \\
\text { mengevaluasi proses mengatasi }\end{array}$ & $\begin{array}{l}\text { Guru membantu siswa untuk melakukan refleksi terhadap } \\
\text { investigasinya (penyelidikannya) dan proses-proses yang } \\
\text { mereka gunakan }\end{array}$ \\
\hline
\end{tabular}

Lembar Kerja Peserta Didik (LKPD) adalah panduan bagi peserta didik untuk melakukan kegiatan penyelidikan atau pemecahan masalah. LKPD ini dapat berupa panduan untuk mengembangkan aspek kognitif maupun panduan untuk mengembangkan semua aspek pembelajaran (Trianto, 2009: 222). LKPD adalah salah satu perangkat pembelajaran yang digunakan dalam proses pembelajaran. Sementara menurut Prastowo (2010) LKPD merupakan materi ajar yang sudah dikemas sedemikian rupa, sehingga peserta didik diharapkan dapat mempelajari materi ajar tersebut secara mandiri. 
Manfaat yang diperoleh dengan menggunakan LKPD antara lain: Memudahkan pendidik dalam mengelola proses belajar, Membantu pendidik mengarahkan peserta didiknya untuk dapat menemukan konsep-konsep melalui aktivitasnya sendiri atau dalam kelompok kerja, Dapat digunakan untuk mengembangkan keterampilan proses dan mengembangkan sikap ilmiah, Membantu pendidik memantau keberhasilan peserta didik untuk mencapai sasaran belajar (Salirawati, 2004) dalam (Noprinda \& Soleh, 2019).

Adapun ciri-ciri LKPD menurut Majid (2013) adalah: a. Memuat semuapetunjuk yang diperlukan peserta didik; b. Petunjuk ditulis dalam bentuk sederhana dengan kalimat singkat dan kosa kata yang sesuai dengan umur dan kemampuan pengguna; c. Berisi pertanyaan-pertanyaan yang harus diisi oleh peserta didik; d. Adanya ruang kosong untuk menulis jawaban serta penemuan peserta didik; e. Memberikan catatan yang jelas bagi peserta didik atas apa yang telah mereka lakukan; $\mathrm{f}$. Memuat gambar yang sederhana dan jelas (Wirdaningsih et al., 2017).

LKPD sangat memungkinkan untuk mengarahkan peserta didik menemukan sendiri konsepkonsep matematika. Tujuan penggunaan lembar kerja peserta didik adalah untuk membantu peserta didik dalam menemukan konsep. LKPD harus dilengkapi dengan pertanyaanpertanyaan analisis yang membantu peserta didik dalam mengaitkan fenomena yang mereka amati dengan konsep yang akan mereka bangun dalam pikiran mereka (Prawoto, 2010) dalam (Putra et al., 2018). Berdasarkan penjelasan tersebut, dapat disimpulkan bahwa LKPD merupakan salah satu perangkat pembelajaran yang berisikan materi ajar yang sudah dikemas sedemikian rupa, yang di dalamnya juga berisikan rangkaian aktivitas dalam penyelidikan, dan diharapkan dapat digunakan peserta didik baik secara berkelompok maupun secara individu.

\section{METODE}

Jenis penelitian yang digunakan adalah penelitian disain (Design Research). Penelitian disain (Design Research) dilaksanakanuntuk mengembangkan dan menghasilkan sebuah produk sebagai suatu solusi dari masalah yang berhubungan dengan pendidikan. Pada penelitian ini, produk yang dihasilkan adalah LKPD berbasis $P B L$ untuk materi matematika semester II kelas VII SMP. Model pengembangan merupakan langkah-langkah yang dilakukan secara sistematis untuk melaksanakan perancangan dan pengembangan LKPD yang diwujudkan dalam bentuk diagram atau naratif. Pada penelitian ini, model pengembangan yang digunakan diadaptasi dari mod el yang dikembangkan oleh Plomp dan dinyatakan sebagai model penelitian Plomp. Model Plomp terdiri dari tiga tahap, yaitu fase analisis pendahuluan (Preliminary Research), fase pengembangan atau pembuatan prototype (Development or Prototyping Phase), dan fase penilaian (Assessment Phase) (Plomp and Nieveen, 2013: 30).

Pada fase pengembangan prototipe (Prototyping Phase) dikembangkan serangkaian prototype. Prototype dievaluasi dengan mengacu pada evaluasi formatif. Evaluasi formatif memiliki beberapa tahapan atau lapisan yang diilustrasikan pada Gambar 1. 


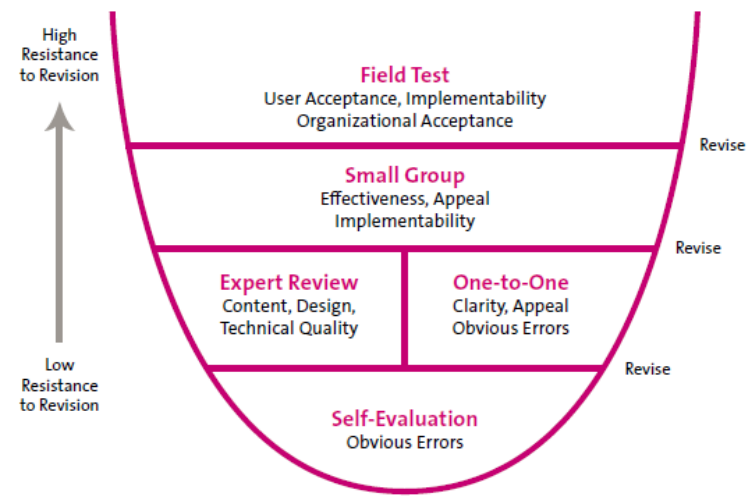

Gambar 1. Lapisan-Lapisan Evaluasi Formatif Model Pengembangan Plomp

(Sumber: Tessmer dalam Plomp and Nieveen (2013))

Selanjutnya, Plomp (Plomp, et al, 2013, P.19) mengemukakan tahapan-tahapan rancangan penelitian, yaitu: Pertama, investigasi awal: Analisis kebutuhan dan konteks, literatur, mengembangkan kerangka konseptual dan teoritis untuk penelitian. Kedua, pengembangan prototipe: Proses perancangan secara siklikal dan berurutan dalam bentuk proses penelitian yang lebih mikro serta menggunakan evaluasi formatif untuk meningkatkan dan memperbaikai intervensi. Ketiga, evaluasi: semi evaluasi sumatif untuk menyimpulkan apakah solusi atau intervensi sudah sesuai dengan yang diinginkan serta mengajukan rekomendasi pengembangan intervensi (Khomsiatun \& Retnawati, 2015).

\section{Teknik Pengumpulan Data}

Jenis data pada penelitian yang akan dilakukan terdiri dari data kualitatif dan kuantitatif. Data kualitatif diperoleh dari data hasil observasi, dan wawancara dengan peserta didik. Sedangkan data kuantitatif didapatkan dari angket.

\section{Teknik Analisis Data}

Adapun teknik analisis data yang digunakan dalam penelitian pengembangan ini yaitu sebagai berikut.

\section{Analisis Data Hasil Validasi LKPD Berbasis PBL}

Data yang berasal dari lembar validasi dianalisis menggunakan analisis kuantitatif. Hasil validasi dari validator terhadap seluruh aspek yang dinilai akan disajikan dalam bentuk tabel. Analisis dilakukan dengan menggunakan skala Likert. Langkah-langkah yang dilakukan untuk menentukan validitas LKPD berdasarkan atas data yang diperoleh dari lembar validasi:

a. Memberikan skor untuk masing-masing skala pada lembar validasi yaitu skor $4=$ sangat setuju,

skor 3 = setuju, skor 2 = tidak setuju, dan skor 1 = sangat tidak setuju

b. Menentukan nilai dengan menggunakan rumus berikut:

$$
R=\frac{\sum_{i=1, j=1}^{i=m, j=n} V_{i j}}{m n}
$$

(Muliyardi, 2006)

Kriteria untuk mendapatkan tingkat kevalidan LKPD sebagai berikut. 
Tabel 1. Kriteria Validitas

\begin{tabular}{|c|c|}
\hline Rata-rata Hasil Penilaian & Interpretasi \\
\hline$R>3,20$ & Sangat Valid \\
\hline $2,40<R \leq 3,20$ & Valid \\
\hline $1,60<R \leq 2,40$ & Cukup Valid \\
\hline $0,80<R \leq 1,60$ & Kurang Valid \\
\hline$R \leq 0,80$ & Tidak Valid \\
\hline
\end{tabular}

\section{Teknik Analisis Data Praktikalitas}

Data praktikalitas dikumpulkan melalui pengisian angket dan wawancara dengan peserta didik. instrumen yang digunakan adalah angket, dan lembar pedoman wawancara.

Angket

Angket respon guru dan peserta didik disusun dalambentuk skala Likert. Skala ini disusun dengan kategori positif sehingga pernyataan positif memperoleh bobot sesuai dengan yang dinyatakan oleh Arikunto (2012). Langkah-langkah menganalisis data angket praktikalitas yaitu sebagai berikut. Memberi skor untuk masing-masing skala sebagai berikut. Bobot 4 untuk pernyataan Sangat Setuju (SS), Bobot 3 untuk pernyataan Setuju (S), Bobot 2 untuk pernyataan Tidak Setuju (TS), Bobot 1 untuk penyataan Sangat Tidak Setuju (STS). Angket praktikalitasLKPD dideskripsikan dengan teknik analisis frekuensi data dengan rumus.

$$
P=\frac{R}{S M} \times 100
$$

Menentukan kriteria kepraktisan. Kriteria kepraktisan menggunakan klasifikasi dapat dilihat di Tabel di bawah ini

Tabel 2. Kriteria Praktikalitas LKPD

\begin{tabular}{|c|c|c|}
\hline No & Tingkat Pencapaian $(\%)$ & Range Persentase \\
\hline 1 & $85 \leq \mathrm{P} \leq 100$ & Sangat Praktis \\
\hline 2 & $75 \leq \mathrm{P}<85$ & Praktis \\
\hline 3 & $60 \leq \mathrm{P}<75$ & Cukup Praktis \\
\hline 4 & $55 \leq \mathrm{P}<60$ & Kurang Praktis \\
\hline 5 & $0 \leq \mathrm{P}<55$ & Tidak Praktis \\
\hline
\end{tabular}

Sumber: (Purwanto, 2006: 103)

\section{HASIL DAN DISKUSI}

\section{Hasil Validasi LKPD dengan Pakar (Expert Review)}

Validasi LKPD dilakukan oleh 2 orang validator yang terdiri dari dosen pendidikan matematika dan dosen Bahasa Indonesia. Sebelum divalidasi beberapa bagian dari LKPD telah mengalami perbaikan atau revisi berdasarkan saran-saran validator. Saran-saran dari validator untuk perbaikan LKPD dapat dilihat pada Tabel di bawah ini 
Tabel 3 Saran Validator untuk Revisi LKPD

\begin{tabular}{|c|c|c|c|}
\hline Validator & Saran & Sebelum Revisi & Sesudah Revisi \\
\hline 1 & $\begin{array}{l}\text { Perlihatkan } \\
\text { langkah-langkah } \\
\text { pada pernyataan } \\
\text { atau } \\
\text { permasalahan } \\
\text { yang akan } \\
\text { dikerjakan } \\
\text { peserta didik. }\end{array}$ & $\begin{array}{l}\text { Pernyataan belum } \\
\text { memperlihatkan permasalahn }\end{array}$ & $\begin{array}{l}\text { Pernyataan dan pertanyaan } \\
\text { sudah memperlihatkan } \\
\text { permasalahan }\end{array}$ \\
\hline 2 & $\begin{array}{l}\text { Penggunaan } \\
\text { kalimat pada } \\
\text { soal diperjelas. }\end{array}$ & $\begin{array}{l}\text { Informasi pada soal latihan } \\
\text { mandiri kurang jelas. }\end{array}$ & $\begin{array}{l}\text { Soal pada latihan mandiri } \\
\text { sudah diperjelas. }\end{array}$ \\
\hline 3 & $\begin{array}{l}\text { Tambahkan } \\
\text { kegiatan } \\
\text { lapangan untuk } \\
\text { menemukan } \\
\text { konsep awal. }\end{array}$ & $\begin{array}{l}\text { Kegiatan pada LKPD dalam } \\
\text { menemukan pemecahan } \\
\text { masalah berpusat pada } \\
\text { penjelasan guru. }\end{array}$ & $\begin{array}{l}\text { Kegiatan pada LKPD sudah } \\
\text { mengajak peserta didik } \\
\text { untuk menemukan } \\
\text { pemecahan masalah yang } \\
\text { ada pada kehidupan peserta } \\
\text { didik }\end{array}$ \\
\hline 4 & $\begin{array}{l}\text { Huruf yang } \\
\text { dipergunakan } \\
\text { disesuaikan } \\
\text { dengan ukuran } \\
\text { standar. } \\
\text { Materi dan } \\
\text { nama penulis } \\
\text { dicantumkan } \\
\text { pada cover. }\end{array}$ & $\begin{array}{l}\text { Ukuran huruf pada LKPD } \\
\text { terlalu besar. }\end{array}$ & $\begin{array}{l}\text { Ukuran huruf sesuai dengan } \\
\text { ukuran standar dalam } \\
\text { penggunaan LKPD. }\end{array}$ \\
\hline 5 & $\begin{array}{l}\text { Perhatikan EYD } \\
\text { dan identitas } \\
\text { penulisan. }\end{array}$ & $\begin{array}{l}\text { Ada beberapa penggunaan } \\
\text { kata yang belum sesuai } \\
\text { dengan EYD, dan } \\
\text { penggunaan tanda titik yang } \\
\text { sering tertinggal. }\end{array}$ & $\begin{array}{l}\text { Penggunaan kata sudah } \\
\text { sesuai dengan EYD dan } \\
\text { pemberian tanda titik pada } \\
\text { akhir kalimat. }\end{array}$ \\
\hline
\end{tabular}

Hasil validasi LKPD berbasis penemuan terbimbing pada semua aspek dapat dilihat pada Tabel di bawah ini.

Tabel 4 Hasil Validasi LKPD Berbasis Problem Based Learning Materi Bilangan.

\begin{tabular}{|l|l|c|c|}
\hline \multicolumn{1}{|c|}{ No. } & \multicolumn{1}{|c|}{ Aspek validasi } & Rata-rata & Kategori \\
\hline 1. & Didaktik & 3,36 & Sangat Valid \\
\hline 2. & Isi & 3,43 & Sangat valid \\
\hline 3. & Bahasa & 3,50 & Sangat valid \\
\hline Rata-rata keseluruhan & 3,43 & Sangat valid \\
\hline
\end{tabular}

Berdasarkan Tabel di atas terlihat bahwa secara umum validitas aspek didaktik, isi dan bahasa pada LKPD berbasis Problem based learning sudah memenuhi kriteria valid dengan rata-rata validitas secara keseluruhan adalah 3,43 dengan kategori sangat valid.

Selanjutnya, terhadap RPP dan LKPD berbasis penemuan terbimbing yang telah diperbaiki disebut prototype II dilakukan uji praktikalitas. Uji praktikalitas bertujuan untuk mengetahui sejauh 
mana manfaat, kemudahan penggunaan dan efesiensi waktu penggunaan LKPD berbasis penemuan terbimbing oleh guru dan peserta didik. Hasil praktikalitas LKPD dideskripsikan sebagai berikut

\section{Praktikalitas LKPD Berbasis Problem Based Learning}

\section{Hasil Angket Tanggapan Siswa Terhadap LKPD Berbasis Problem Based Learning}

Data praktikalitas LKPD berbasis Problem Based Learning diperoleh dari angket respon guru dan angket peserta didik pada kelompok besar. Data hasil uji coba yang diperoleh, diuraikan sebagai berikut. Angket tanggapan peserta didik terhadap LKPD yang digunakan diberikan pada ahir peretemuan yaitu pada pertemuan ketiga. Peserta didik yang mengisi angket berjumlah 15 orang. Tanggapan peserta didik terhadap LKPD yang digunakan sangat positif. Rekapan tanggapan peserta didik dapat dilihat pada tabel 3 di bawah ini:

Tabel 5. Hasil Angket Tanggapan Siswa Terhadap LKPD

\begin{tabular}{|c|l|c|}
\hline No & \multicolumn{1}{|c|}{ Kriteria } & Hasil \\
\hline 1 & Sangat Setuju & $33,33 \%$ \\
\hline 2 & Setuju & $53,33 \%$ \\
\hline 3 & Tidak Setuju & $13,33 \%$ \\
\hline 4 & Sangat Tidak Setuju & $0 \%$ \\
\hline
\end{tabular}

Sumber: Data Penelitian

Tabel 3 merupakan hasil rekapan tanggapan siswa terhadap LKPD yang digunakan pada saat pembelajaran. Dari tabel dapat dilihat bahwa peserta didik setuju dengan LKPD yang digunakan, hanya satu orang yang tidak setuju. Jumlah pertany aan yang diberikan pada angket berjumlah 15 pertanyaan yang mencakup pertanyaan mengenai penampilan LKPD dan materi yang ada pada LKPD.

Jawaban yang tertinggi dari tanggapan siswa tiap aspek perny ataan dalamangket adalah pernyataan nomor tiga, empat, tujuh dan delapan bahwa rata-rata siswa menjawab setuju dan sangat setuju. Pertanyaan nomor tiga, empat, tujuh dan delapan secara beruurutan yaitu Saya menyukai ukuran dan jenis huruf yang digunakan dalam LKPD, Saya menyukai ukuran kertas LKPD karena memudahkan saya untuk menggunakan dan membawanya, Saya menyukai tampilan halaman cover dan isi yang terdapat pada LKPD berbasis $P B L$, Saya dapat memahami permasalahan yang disajikan pada LKPD. Tanggapan peserta didik pada setiap pernyataan dapat dilihat dibawan ini:

Tabel.6 Rekapiltulasi Tanggapan Siswa Tiap Butir Pernyataan Angket

\begin{tabular}{|c|l|l|l|l|}
\hline $\begin{array}{c}\text { No } \\
\text { Pernyataan }\end{array}$ & $\begin{array}{c}\text { Sangat Setuju } \\
(4)\end{array}$ & \multicolumn{1}{|c|}{ Setuju (3) } & $\begin{array}{c}\text { Tidak Setuju } \\
(2)\end{array}$ & $\begin{array}{c}\text { Sangat } \\
\text { Tidak } \\
\text { Setuju (1) }\end{array}$ \\
\hline 1 & $5(33,33 \%)$ & $9(60 \%)$ & $1(6 \%)$ & \\
\hline 2 & $6(40 \%)$ & $9(60 \%)$ & & \\
\hline 3 & $12(80 \%)$ & $3(20 \%)$ & & \\
\hline 4 & $14(93,33 \%)$ & $1(6 \%)$ & & \\
\hline 5 & $10(66,66 \%)$ & $2(13,33 \%)$ & $3(20 \%)$ & \\
\hline 6 & $6(40 \%)$ & $8(53,33 \%)$ & $1(6 \%)$ & \\
\hline 7 & $13(86,66 \%)$ & $2(13,33 \%)$ & & \\
\hline 8 & $12(80 \%)$ & $3(20 \%)$ & & \\
\hline 9 & $5(33,33 \%)$ & $8(53,33 \%)$ & $2(13,33 \%)$ & \\
\hline
\end{tabular}




\begin{tabular}{|l|l|l|l|l|}
\hline 10 & $7(46,66 \%)$ & $8(53,33 \%)$ & & \\
\hline 11 & $4(26,66 \%)$ & $9(60 \%)$ & $2(13,33 \%)$ & \\
\hline 12 & $6(40 \%)$ & $7(46,66 \%)$ & $2(13,33 \%)$ & \\
\hline 13 & $7(46,66 \%)$ & $7(46,66 \%)$ & $1(6 \%)$ & \\
\hline 14 & $9(60 \%)$ & $5(33,33 \%)$ & $1(6 \%)$ & \\
\hline 15 & $7(46,66 \%)$ & $8(53,33 \%)$ & & \\
\hline
\end{tabular}

Nilai praktikalitas dihitung dengan menggunakan rumus

$$
\begin{aligned}
& P=\frac{R}{S M} \times 100 \% \\
& P=\frac{812}{900} \times 100 \%=90,2 \%
\end{aligned}
$$

Dari hasil di atas diperoleh nilai praktikalitas $90,2 \%$, berdasarkan table praktikalitas bahwa nilai praktikalitas bernilai sangat praktis. Angket pada LKPD disediakan tempat penulisan saran, namun tidak ada peserta didik yang menuliskan. Secara tidak langsung peserta didik mengungkapkan bahwa di KLPD kurang adanya gambar yang menarik. Pada saat sela sela pengisian angket terdengar peserta didik untuk menyarankan adanya LKPD untuk mata pelajaran lainnya. Berdasarkan table tiga dan empat dapat diketahui bahwa secara keseluruhan peserta didik memberikan tanggapan yang positif terhadap LKPD berbasis PBL yang digunakan.

\section{Hasil Angket Tanggapan Guru Terhadap LKPD Berbasis Problem Based Learning pada Materi Bilangan Bulat}

Guru diminta juga untuk mengisi angket terhdap LKPD yang sudah diujicobakan pada kelompok besar. Hasil analisis tanggapun guru mengenai LKPD pada materi bilangan bulat mendapatkan tanggapan yang positif. Hasil angket tanggapan guru terhadap LKPD yang dibuat dapat dilihat pada tabel 5 di bawah ini:

Tabel 7. Tanggapan Guru Terhadap LKPD dengan Materi Bilangan Bulat

\begin{tabular}{|l|l|l|l|l|l|}
\hline \multirow{2}{*}{ No } & \multicolumn{1}{|c|}{ Aspek yang ditanyakan } & \multicolumn{3}{|c|}{ Jawaban } \\
\cline { 3 - 5 } & & $\begin{array}{l}\text { STS } \\
(1)\end{array}$ & $\begin{array}{l}\text { TS } \\
(2)\end{array}$ & $\begin{array}{l}\text { S } \\
(3)\end{array}$ & $\begin{array}{l}\text { SS } \\
(4)\end{array}$ \\
\hline 1 & Petunjuk pada LKPD jelas sehingga mudah dipahami & & & $\sqrt{ }$ & \\
\hline 2 & $\begin{array}{l}\text { LKPD dibuat dengan jenis dan ukuran tulisan yang dapat menarik } \\
\text { perhatian peserta didik }\end{array}$ & & & $\sqrt{ }$ \\
\hline 3 & $\begin{array}{l}\text { LKPD dibuat dengan warna-warna yang dapat menarik perhatian } \\
\text { peserta didik untuk menggunakannya }\end{array}$ & & & $\sqrt{ }$ \\
\hline 4 & $\begin{array}{l}\text { LKPD dibuat dengan ukuran kertas yang dapat memudahkan } \\
\text { peserta didik untuk menggunakannya }\end{array}$ & & & $\sqrt{ }$ \\
\hline 5 & $\begin{array}{l}\text { Penggunaan visualiasi gambar pada LKPD menunjang kejelasan } \\
\text { permasalahan yang disajikan pada setiap pokok bahasan }\end{array}$ & & $\sqrt{ }$ & \\
\hline 6 & $\begin{array}{l}\text { Penyajian permasalahan pada LKPD sesuai dengan kriteria } \\
\text { masalah yaitu kontekstual, non-rutin, }\end{array}$ & & & $\sqrt{ }$ \\
\hline 7 & $\begin{array}{l}\text { Kegiatan pembelajaran pada tiap pokok bahasan jelas, yaitu sesuai } \\
\text { dengan fase Problem Based Learning yang diawali dengan } \\
\text { pemberian permasalahan dan diikuti dengan penyelesaian masalah } \\
\text { melalui tahapan menemukan dan mendefinisikan masalah, }\end{array}$ & & & & $\sqrt{ }$ \\
\hline
\end{tabular}




\begin{tabular}{|l|l|l|l|c|c|}
\hline & $\begin{array}{l}\text { mengumpulkan data/ fakta, mengajukan hipotesis, melakukan } \\
\text { penyelidikan dan menarik kesimpulan }\end{array}$ & & & \\
\hline 8 & Kegiatan pada LKPD dapat dengan mudah dilaksanakan & & & $\sqrt{ }$ & \\
\hline 9 & $\begin{array}{l}\text { penggunaan lkpd dapat memudahkan guru dalam membantu } \\
\text { peserta didik menemukan/mengkonstruksi konsep bilangan }\end{array}$ & & & & $\sqrt{ }$ \\
\hline 10 & $\begin{array}{l}\text { Kegiatan yang terdapat dalam LKPD dapat melatih keterampilan } \\
\text { peserta didik dalam menyelesaikan masalah }\end{array}$ & & & & $\sqrt{ }$ \\
\hline 11 & Penggunaan huruf, kata, atau kalimat yang mudah dibaca & & & $\sqrt{ }$ & \\
\hline 12 & $\begin{array}{l}\text { Bahasa yang dipakai mudah dipahami sehingga dapat membantu } \\
\text { peserta didik untuk menemukan solusi dari permasalahan yang } \\
\text { diberikan }\end{array}$ & & & $\sqrt{ }$ \\
\hline 13 & $\begin{array}{l}\text { Penggunaan LKPD dapat membantu guru dalam memanfaatkan } \\
\text { alokasi waktu yang tersedia pada setiap pertemuan }\end{array}$ & & & & $\sqrt{ }$ \\
\hline & Jumlah & & & 12 & 36 \\
\hline
\end{tabular}

Nilai praktikalitas dihitung dengan menggunakan rumus

$$
\begin{aligned}
& P=\frac{R}{S M} \times 100 \% \\
& P=\frac{48}{52} \times 100 \%=92 \%
\end{aligned}
$$

Dari hasil di atas diperoleh nilai praktikalitas $92 \%$, berdasarkan table praktikalitas bahwa nilai praktikalitas bernilai sangat praktis. Angket yang sudah di isi guru sangat positif yaitu hampir semua jawaban sangat setuju, kecuali ada di pernyataan nomor empat, lima, delapan dan sebelas. Komentar guru pada pernyataan nomor empat yaitu menurut guru bahwa LKPD yang digunakan sudah cukup bagus, namun akan lebih bagus lagi jika kertas yang digunakan pada LKPD kertas yang tebal agar LKPD awet dan tahan lama disimpan oleh siswa. Komentar guru pada pernyataan nomor lima bahwa LKPD sudah bagus namun akan lebih baik lagi jika ditambahkan gambar-gambar yang berkaitan dengan materi. Komentar LKPD pada pertnyataan nomor delapan yaitukegiatan pada LKPD banyak menggunakan kata-kata, sehingga banyak memunculkan pertanyaan oleh siswa. Komentar guru pada pernyataan nomor sebelas yaitu bahasayang digunakan pada LKPD sudah bagus, namun dengan panjangnya persmasalahan membuat peserta harus membaca persoalan lebih dari sekali baca.

Validitas isi dan validitas konstruk dikaji melalui penilaian oleh pakar (validator) yang telah ditentukan. Berdasarkan hasil validasi yang dilakukan terhadap satu orang pakar pendidikan matematikadan satu orang pakar Bahasa Indonesia, maka dapat disimpulkan bahwa LKPD berbasis Problem Based Learning telah memenuhi aspek didaktik, aspek isi dan aspek bahasa yang telah ditetapkan. Berdasarkan semua aspek yang dinilai berada dalam kategori sangat valid. Hal ini berarti bahwa berdasarkan para ahli LKPD berbasis Problem Based Learning ini sudah dapat digunakan dalam proses pembelajaran.

Berdasarkan angket praktikalitas respon pesertadidik diketahui bahwa rata-rata secara keseluruhan angket dalam kategori sangat prkatis. Namun, terdapat beberapaperbaikan yang dilakukan dari beberapa kendala yang ditemui. Perbaikan yang dilakukan yaitu kejelasan perintah soal dan kolom penyelesaian dari soal yang diberikan, serta bahasa yang digunakan. 
Pengembangan Lembar Kerja Peserta Didik (LKPD) Berbasis Problem Based Learning (PBL) untuk Kelas VII SMP/MTs

Selanjutnya data praktikalitas pada uji lapangan diperoleh melalui angket guru dan peserta didik. Berdasarkan hasil angket yang diisi oleh guru diketahui bahwa LKPD pembelajaran matematika dengan berbasis Problem Based Learning memiliki rata-rata secara keseluruhan dalam kategori sangat paktis. Hal ini menunjukkan bahwa LKPD sudah memudahkan guru dalam pelaksanaan pembelajaran.

\section{KESIMPULAN}

Hasil validasi dari para validator menunjukkan bahwa telah dihasilkan LKPD berbasis Problem Based Learning yang valid baik dari segi isi, konstruk, dan bahasa, dengan karakteristik seperti LKPD yang dihasilkan telah disesuaikan dengan ciri-ciri dari Problem Based Learning yaitu Orientasi siswa pada masalah, Mengorganisasikan siswa untuk belajar, Membimbing penyelidikan individual maupun kelompok, Mengembangkan dan menyajikan hasil karya, Menganalisa dan mengevaluasi proses pemecahan masalah. Hal inilah yang menjadi salah satu ciri khas dari LKPD berbasis Problem Based Learning yang dihasilkan. Ciri lain atau karakteristik lain yang dimiliki oleh LKPD berbasis Problem Based Learning adalah adanya pertanyaan-pertanyaan yang dapat membantu peserta didik dalam menyelesaikan masalah yang disajikan. Jika pada bahan ajar lain tidak disajikan bagaimana seharusnya peserta didik menyelesaiakan masalah yang diberikan maka pada LKPD berbasis Problem Based Learning disajikan langkah-langkah yang dapat digunakan peserta didik dalam memecahkan masalah.

Berdasarkan hasil penelitian juga telah dihasilkan LKPD yang memenuhi kriteria praktis dengan karakteristik yaitu adanya kemudahan dalam penggunaan LKPD berbasis Problem Based Learning. Kejelasan petunjuk penggunaan LKPD berbasis Problem Based Learning, kejelasan petunjuk belajar, dan kejelasan petunjuk pelaksanaan kegiatan yang disajikan pada tiap pertemuan akan memberikan kemudahan bagi pengguna dalam menggunakan perangkat pembelajaran berbasis Problem Based Learning. Karakteristik lainnya seperti adanya pemberian ilustrasi/ gambar pada LKPD berbasis Problem Based Learning yang dapat mendukung untuk memahami permasalahan yang disajikan.

\section{UCAPAN TERIMA KASIH}

Terimakasih saya ucapkan kepada Rektor Universitas Pahlawan Tuanku Tambusai yang telah membantu mendanai penelitian ini. Terimakasih juga saya ucapkan kepada guru matematika MTsN 6 Kampar yang telah bersedia untuk mengambil data dalam penelitian ini.

\section{REFERENSI}

Astuti, S., Danial, M., \& Anwar, M. (2018). PENGEMBANGAN LKPD BERBASIS PBL (PROBLEM BASED LEARNING) UNTUK MENINGKATKAN KETERAMPILAN BERPIKIR KRITIS PESERTA DIDIK PADA MATERI KESETIMBANGAN KIMIA. Chemistry Education Review (CER). https://doi.org/10.26858/cer.v0i1.5614

Arikunto. 2012. Prosedur Penilaian: Suatu Pendekatan Praktek. Jakarta: Rineka Cipta.

Kamarullah, K. (2017). PENDIDIKAN MATEMATIKA DI SEKOLAH KITA. Al Khawarizmi: Jurnal Pendidikan Dan Pembelajaran Matematika. https://doi.org/10.22373/jppm.v 1 i1.1729 
Khomsiatun, S., \& Retnawati, H. (2015). PENGEMBANGAN PERANGKAT PEMBELAJARAN DENGAN PENEMUAN TERBIMBING UNTUK MENINGKATKAN KEMAMPUAN PEMECAHAN MASALAH. Jurnal Riset Pendidikan Matematika. https://doi.org/10.21831/jrpm.v2i1.7153

Kunandar. 2011. Guru Profesional: Impelentasi Kurikulum Tingkat Satuan Pendidikan (KTSP) dan Sukses dalam Sertifikasi Guru. Jakarta: Rajawali Press.

Muliyardi. 2002. Strategi Pembelajaran Matematika. Padang: UNP.

Nafiah, Y. N., \& Suyanto, W. (2014). Penerapan model problem-based learning untuk meningkatkan keterampilan berpikir kritis dan hasil belajar siswa. Jurnal Pendidikan Vokasi. https://doi.org/10.21831/jpv.v4i1.2540

Noprinda, C. T., \& Soleh, S. M. (2019). Pengembangan Lembar Kerja Peserta Didik (LKPD) Berbasis Higher Order Thinking Skill (HOTS). Indonesian Journal of Science and Mathematics Education. https://doi.org/10.24042/ijsme.v2i2.4342

Putra, A., Syarifuddin, H., \& Zulfah, Z. (2018). Validitas Lembar Kerja Peserta Didik Berbasis Penemuan Terbimbing dalam Upaya Meningkatkan Pemahaman Konsep dan Kemampuan Penalaran Matematis. Edumatika: Jurnal Riset Pendidikan Matematika. https://doi.org/10.32939/ejrpm.v1i2.302

Prastowo, Andi. Panduan Kreatif Membuat Bahan Ajar Inovatif. Jogjakarta: Diva Press.

Rahmah, N. (2018). Hakikat Pendidikan Matematika. Al-Khwarizmi: Jurnal Pendidikan Matematika Dan Ilmu Pengetahuan Alam. https://doi.org/10.24256/jpmipa.v 1i2.88

Rifa'i, R. (2019). Penerapan Model Problem Based Learning untuk Meningkatkan Kemampuan Pemecahan Masalah Matematis Siswa. Jurnal Kajian Pendidikan Matematika, 5(1), 109-116.

Suhendar, U., \& Ekayanti, A. (2018). ProblemBasedLearning Sebagai Upaya Peningkatan Pemahaman Konsep Mahasiswa. Jurnal Dimensi Pendidikan Dan Pembelajaran.

Sumartini, T. S. (2018). Peningkatan Kemampuan Pemecahan Masalah Matematis Siswa melalui Pembelajaran Berbasis Masalah. Mosharafa: Jurnal Pendidikan Matematika. https://doi.org/10.31980/mosharafa.v5i2.270

Susanti, S., Duskri, M., \& Rahmi, M. (2019). Peningkatan Kemampuan Representasi Matematis melalui Model Problem-Based Learning pada Siswa SMP/MTs. Suska Journal of Mathematics Education. https://doi.org/10.24014/sjme.v5i2.7357

Wirdaningsih, S., Arnawa, I. M., \& Anhar, A. (2017). Pengembangan Perangkat Pembelajaran Matematika dengan Pendekatan Contextual Teaching and Learning untuk Meningkatkan Kemampuan Pemecahan Masalah Peserta Didik Kelas XI. JNPM (Jurnal Nasional Pendidikan Matematika). https://doi.org/10.33603/jnpm.v1i2.535 